\title{
Background, Responsibility, and Excuse
}

\author{
George Vuoso
}

\section{INTRODUCTION}

It is a widely held belief that a disadvantaged socio-economic background can mitigate or eliminate responsibility for crime. Though severe environmental deprivation simpliciter is generally not recognized as a criminal defense, ${ }^{1}$ it has had and continues to have its supporters. ${ }^{2}$ Even if it is not explicitly recognized or supported as a defense, it may remain a significant consideration in sentencing, parole, and pardon decisions. ${ }^{3}$

I will argue against the notion that an adverse early social background is a factor that can mitigate one's moral and criminal responsibility for

1. See H. Packer, The Limits of the Criminal. Sanction 133 (1968).

2. See, e.g., Bazelon, The Morality of the Criminal Law, 49 S. Cal. L. Rev. 385 (1976) [hereinafter Bazelon I] (argues for recognition of disadvantaged background as possible defense based on requiring moral responsibility for criminal responsibility); Bazelon, The Morality of the Criminal Law: A Rejoinder to Professor Morse, 49 S. CAl.. L. REv. 1269 (1976) (defends his position against criticisms based on impracticality); Delgado, "Rotten Social Background": Should the Criminal Law Recognize a Defense of Severe Environmental Deprivation?, 3 Law \& INF.Qual.rTY 9 (1985) (argues for recognition of such defense); see also United States v. Alexander, 471 F.2d 923, 957-65 (D.C. Cir. 1973) (as amended) (Bazelon, C.J., for majority and dissenting in part) (questions whether black youth from ghetto background can be held responsible for killing marine who taunted him with racial epithet), cert. denied, 409 U.S. 1044 (1972); Washington v. United States, 390 F.2d 444, 453 (D.C. Cir. 1967) (Bazelon, C.J.) (insanity case) (" $\Lambda$ proper adjudication requires that the jury be fully informed about the defendant's mental and emotional processes and, insofar as it affects these processes, his social siluation."); authorities cited infra note 18.

3. See, e.g., United States v. Torniero, 570 F. Supp. 721 (D. Conn. 1983):

$\Lambda \mathrm{n}$ accused drug trafficker, for example, might claim that when one considered the impoverished environment in which he grew up, the failure of the state to provide him with an enlightened moral education, and the frequency and social acceptance of drug use in his neigh-

borhood, one could not say that he acted with complete volition. . . [F]ew if any would characterize him as insane. . . That does not mean, of course, that the facts concerning his background would have no place in the criminal justice system: rather, it means that those facts would bear upon his sentence instead of upon his conviction[l.

Id. at 729; G. TAl.ESE, HoNOR THY FATHER (1971) (quoting Judge Mansfield's remarks before imposing sentence on Salvatore (Bill) Bonanno in 1970 following Bonanno's conviction for mail fraud and other crimes):

I don't think that you are a victim of circumstances.

You have had a relatively good education .... You have had comforts provided you in your youth, and there is hardly any excuse for the type of conduct of which you were found guilty here. ... You are not the product of a ghetto. . . Y You could have gotten a job. There was no need to do what you did.

Id. at 483; see also United States v. Barker, 514 F.2d 208, 236 (D.C. Cir.) (Bazelon, C.J., concurring) ("There are many 'escape valves' in the law which permit largely unreviewable discretion for certain officials to mitigate harshness caused by the law's inability to meet its highest ideals, including the ideal of punishing only the free choice to do wrong."), cert. denied, 421 U.S. 1013 (1975); Glazebrook, The Necessity Plea in English Criminal Law, 30 CAmbridge L.J. 87, 117-19 (1972) (concludes that under English criminal justice system, courts deal with "special cases" such as those involving necessity by exercising their wide discretion in sentencing). 
one's later actions, by identifying and arguing against the philosophical tradition in which the notion is embedded. Two of the distinguishing features of this tradition are its rejection of determinism, the thesis that every event is caused, ${ }^{4}$ and its acceptance of the causal theory of excuse, which asserts that an agent is not responsible for an act that he was caused to perform by factors outside his control or external to his will. ${ }^{5}$ I will demonstrate that a standard sort of argument against the causal theory of excuse based on moral experience is unsatisfactory, and will present a purely conceptual argument that is more conclusive.

The alternative conception of responsibility I will urge is based on the relationship between action and character. This conception will be offered as a rationale for the generally recognized legal excuses, and as a standard for deciding whether novel or controversial factual circumstances should be considered to excuse; its relevance to the insanity defense in particular will be briefly discussed. I will close by applying the proposed conception of responsibility to support the recognition of one's present socio-economic "background" or circumstances, as opposed to one's past or early background, as a possible factor mitigating responsibility.

I will not attempt to present a theory or formula of sufficient detail as to yield clear answers with respect to responsibility in any case that can arise. My concerns are more general and theoretical, though some practical consequences will be clear. The underlying goal is to present in general, basic terms what I believe is the best way for the criminal law to deal with the issues of free will and determinism.

\section{Retaining a Place for Morality in the Griminal Law}

\section{A. Moral and Legal Responsibility}

The responsibility at issue here is responsibility for actions. ${ }^{6}$ I will consider moral responsibility to be simply blameworthiness, and legal respon-

4. There are various versions of determinism, but for present purposes this simple definition will suffice, provided that the thesis that every event is caused is taken to entail that all events are inevitable and in principle predictable.

5. See Moore, Causation and the Excuses, 73 Cal.rf. L. Rfv. 1091, 1091 (1985) (causal theory of excuse explained and challenged). Sources supporting the causal theory of excuse in some form include C. DARROW, ATTORNEY FOR THE. DAMNED 80 ( $\Lambda$. Weinberg ed. 1957) (" $\Lambda] l l$ punishment proceeds upon the theory that there is no cause [for a criminal act] . . . "); Broad, Determinism, Indeterminism, and Libertarianism, in Frrf. Whi.. AND Dr:rfrminism 135 (B. Berofsky ed. 1966) (contending in effect that moral responsibility entails indeterminism); Hart \& Honoré, Causation in the Law (pt. 1), 72 LAw Q. Rkv. 58, 80 (1956) (contending that free and deliberate human action is never considered to be itself caused); Hospers, What Means This Freedom?, in FREE WILI. AND Dr:Irkmintsm, supra, at 26 (contending that, at the deepest level of moral discourse, causation of actions eliminates responsibility for them). But see J. Feinberg, Causing Voluntary Actions, in DoING AND Deskeving 152, 152 (1970) (arguing against thesis that "every voluntary human action is a new causal start, a kind of prime mover or uncaused cause").

6. For a discussion of other types of responsibility (e.g., responsibility for one's children, for an- 
sibility to be the liability under a legal system to suffer some penalty or to pay compensation under certain conditions. ${ }^{7}$ Criminal responsibility is a type of legal responsibility.

Whatever one's position on whether moral and legal responsibility are logically related, it is a plain fact that in practice our criminal law is such that people are generally held criminally responsible only when they would also be held morally responsible. ${ }^{8}$ Such an overlap between moral and criminal responsibility is supported by practical as well as moral considerations: Only a criminal law that incorporated to some extent the morality of the society it was supposed to serve, could hope to endure and effectively achieve general deterrence and the other societal benefits that are thought to justify criminal punishment. ${ }^{9}$ If our legal system departs too greatly from morality, "there is a risk of either confusing common morality or flouting it and bringing the law into contempt."10

A significant convergence of law and morality can be accomplished by honoring and implementing the basic moral principle that, other things being equal, it is morally wrong to punish someone who has not done something for which he is morally blameworthy. ${ }^{11}$ This "punishment principle" is a fundamental premise and motivating force of this Note.

other's debt, for some catastrophe), and for a careful analysis of the concept of responsibility in general, see H.L.A. HAR', Postscript: Responsibility and Retribution, in PUNISHMENT AND ResPONSIBII.TYY 210 (1968).

7. These interpretations of moral and legal responsibility are fairly standard, though there are others. Moral responsibility, for example, can be used as a neutral term to cover both cases of blameworthiness and praiseworthiness. See, e.g., Fischer, Introduction: Responsibility and Freedom, in Moral. RtisponsibII.TYY 9, 12-13 (J. Fischer ed. 1986). See generally H.L.A. HART, supra note 6.

8. See, e.g., Morissette v. United States, 342 U.S. 246, 252 (1952) ("[C]ourts of various jurisdictions. . . have sought to protect those who were not blameworthy in mind from conviction of infamous common-law crimes."); United States v. Moore, 486 F.2d 1139, 1240-41 (D.C. Cir.) (Wright, J, dissenting) ("The concept of criminal responsibility is, by its very nature, 'an expression of the moral sense of the community." ") (quoting United States v. Freeman, 357 F.2d 606, 615 (2d Cir. 1966)), cert. denied, 414 U.S. 980 (1973); Durham v. United States, 214 F.2d 862, 876 (D.C. Cir. 1954); Holloway v. United States, 148 F.2d 665, 666-67 (D.C. Cir. 1945) ("Our collective conscience does not allow punishment where it cannot impose blame."); United States v. Torniero, 570 F. Supp. 721, 731 (D. Conn. 1983); Note, Regulating the Criminal Conduct of Morally Innocent Persons: The Problem of the Indigenous Defendant, 6 B.C. THIRd Worl.D L.J. 161, 161 (1986).

9. Even Oliver Wendell Holmes, that staunch advocate of a clear separation of law from morality, acknowledged the practical importance of a considerable convergence of moral and criminal responsibility:

[The assertion that] the purpose of the criminal law is only to induce external conformity to

rule. ...

...

. . . is not intended to deny that criminal liability, as well as civil, is founded on blameworthiness. Such a denial would shock the moral sense of any civilized community; or, to put it another way, a law which punished conduct which would not be blameworthy in the average member of the community would be too severe for that community to bear.

O.W. Hol.ases, Thr CoMmon Law 42 (1963).

10. Hart, Prolegomenon to the Principles of Punishment, in Punishment and Responsibility, supra note 6 , at 25 .

11. This basic principle is acknowledged in Holloway v. United States, 148 F.2d at 666-67; see also authorities cited supra note 8. 
The principle is not absolute; it does not entail that it is never morally defensible to punish someone who has not voluntarily committed a moral wrong, but only that it violates a moral principle to do so, which must be justified by some other competing moral principle or principles that outweigh it, or by a substantial gain in utility. ${ }^{12}$

\section{B. Determinism and the Voluntary Act Requirement}

By accepting, even in a qualified form, that moral responsibility is a requirement for criminal responsibility, one makes determinism, which has long been a problem for the former, a problem for the latter as well. Determinism seems to bear on criminal responsibility in any case, however, since the criminal law in virtually all advanced legal systems, including our own, has incorporated in some form the requirement that for a person to be liable to punishment, at least for the more serious offenses, he must have acted voluntarily. ${ }^{13}$ A person's doing something voluntarily is generally considered to imply that he exercised his free will in doing it, or that he could have done otherwise. ${ }^{14}$ Thus, the free will-determinism problem rears its head. ${ }^{15}$

The incorporation of a voluntary act requirement in the criminal law of a society can itself be seen as an indication that the society does not want

12. The reason a substantial rather than a bare or marginal gain in utility is required to overcome this punishment principle, is precisely because it is a fundamental moral principle; if the barest increase in utility could trump it, then utility itself would be the fundamental or ultimate principle. $C f$. R. Dworkin, Taking Rights Seriously, in Taking; Ricirts Srrousi.y 184, 191-92 (1978) (a moral right cannot be overridden by marginal utility gain). If this punishment principle were absolute, on the other hand, then no amount of gain in utility could overcome it.

Among the factors limiting the principle are administrative considerations, including burdens of proof or evidentiary problems, and also the lack of a clear moral consensus on many moral issues. As a bare minimum, one might insist that the principle apply with respect to punishment for the most serious crimes. IV.

For a discussion of this punishment principle as the foundation for legal excuses, see infra Section

13. See, e.g., Modei. Penal. Code and Commentarits $\$ 2.01(1) \&$ comment 1 at 218 (Official Draft and Revised Comments 1985) [hereinafter MODFi. PENAL. CoDE] (" $\Lambda$ person is not guilty of an offense unless his liability is based on conduct that includes a voluntary act or the omission to perform an act of which he is physically capable." Id. \$ 2.01(1).); see also Morissette v. United States, 342 U.S. 246, 250 (1952); Hart, Legal Responsibility and Excuses, in Punishment and RfsponsibilITY, supra note 6, at 28, 28; 4 W. Bl.ACKsIONE, CoMmentaries 20-21 (1769) ("[T] of the will, when it has it's [sic] choice either to do or to avoid the [act] in question, [is] the only thing that renders human actions either praiseworthy or culpable.").

14. The traditional notion that acting freely or voluntarily implies the ability to do otherwise has become controversial. See, e.g., Frankfurt, Alternate Possibilities and Moral Responsibility, in MORAl. RESPONSIBH.ITY, supra note 7, at 143 (discusses apparent counterexamples to this traditional notion); Fischer, supra note 7 , at 51-55 (same).

15. This problem in brief is the following. The basic determinist thesis that every event is caused is intuitively appealing and widely held. Associated with this thesis is the conviction that if actions, as a species of event, are causally inevitable and in principle predictable in advance, then there is no free will. But the position that people do have free will is also intuitively appealing and popular. The conflict between these two intuitively appealing and commonly held views is the free will-determinism problem. 
moral and legal responsibility to diverge too greatly. A basic necessary condition for a person's being morally responsible for an act is that he performed it voluntarily. Requiring a voluntary act for criminal responsibility as well is a first step toward honoring the fundamental punishment principle presented above. One need not justify the voluntary act requirement in this way, however. ${ }^{16}$ The free will-determinism issue may be dispensed with insofar as criminal responsibility is concerned by dissociating the latter entirely from moral responsibility. ${ }^{17}$ It is not necessary to go to such extremes to dispel worries posed by determinism, however, as I will demonstrate.

The discussion and arguments to follow will in large measure deal more directly with moral than with legal responsibility; their relevance to the latter derives from the close connection between moral and criminal responsibility that exists in fact, and that is desirable on principled and practical grounds.

\section{Mitigation of Responsibility and EARly Background}

If an armed robber came from a wretchedly poor environment, never knew his parents, was regularly beaten as a young child, and grew up on the streets surrounded by crime, drug addiction, and other bad influences, he would commonly not be considered to be as morally or as legally responsible as he would be if he grew up with all of the advantages. ${ }^{18}$ I will refer to the view that such a person's responsibility is mitigated by such circumstances and events in his past as the "Mitigation Due to Early Background" ("MDEB") position. The most plausible, or at least a very common, rationale for this position is based on the causal theory of excuse. ${ }^{19}$ In particular, MDEB proponents typically would consider that the

16. See, e.g., Hart, supra note 10 (discussion of utilitarian and fairness rationales for voluntary act requirement).

17. See infra text accompanying notes 53-55, and note 53 .

18. See, e.g., Campbell, Is "Freewill" a Pseudo-Problem?, in Free Wil. and Determinism, supra note 5 , at 112,115 ("It is our normal habit to 'make allowances' . . . when we have reason to believe that a malefactor had a vicious heredity, or was nurtured in his formative years in a harmful environment. We say in such cases 'Poor chap, he is more to be pitied than blamed." ); Delgado, supra note 2, at 10-12, 23-37 (argues that there is causal link between environmental deprivation and crime, in order to establish rationale for "Mitigation Due to Early Background" position); Wolf, Asymmetrical Freedom, in MoRAL. RrSPONSIBII.IrY, supra note 7, at 225, 229; see also Bazelon I, supra note 2, at 389; Morris, Psychiatry and the Dangerous Criminal, 41 S. CAL. L. Rrv. 514, 520 (1968) (contending that because "la]dverse social and subcultural background is statistically more criminogenic than is psychosis," it may mitigate moral responsibility for crime).

19. See supra text accompanying note 5; Moore, supra note 5, at 1091; see also authorities cited supra note 18.

Other rationales have been offered for the MDEB position. One of these is a sympathy rationale: Those from a severely disadvantaged past should not be held as responsible for any crimes they might later commit because they have already suffered enough. See, e.g., Moore, supra, at 1146. This sympathy rationale is not without appeal, but it is beset with conceptual and practical problems. For one 
armed robber's unfortunate background caused him to go wrong, or rather, that to the extent that it caused him to go wrong, he is not morally or criminally responsible for his crime. ${ }^{20}$ On the other hand, if he had come from a good or a more normal background, they would have thought that he would have had more control over his later behavior, so as to make him more fully responsible for any crime he might commit. In other words, they would think that because his past included these unfortunate circumstances and events, it was such that it was likely to have caused

thing, it does not seem that a "disadvantaged" past would necessarily involve a great deal of suffering, or significantly more than the average person experiences. One born to poverty, growing up without much family support and surrounded by criminal influences, might, due to genetic factors, be very resilient psychologically and might adapt well to his circumstances. He could conceivably turn to crime quickly, be successful at it, and enjoy it. On the other hand, a criminal from an advantaged background might have been genetically disposed to depression, and his criminality might every bit as much have been a causal product of his past.

Thus, what this sympathy rationale would really support would be a "suffering" defense, not a "rotten social background" defense or the MDEB position. But surely, a suffering defense would be totally impractical. It could be raised with respect to any criminal and any crime. Everyone has suffered. What is the average amount of suffering? When has one suffered enough? One's history of suffering is simply not directly relevant to the purposes of, or the rationales or justifications for, criminal punishment. (Though one's history of suffering in itself may not merit treatment as a defense or as a factor affecting responsibility, it may perhaps call for a mitigation of punishment strictly on mercy grounds.)

Another rationale that has been offered for the MDEB position is the "social contract" rationale. See, e.g., P. Ril.hy, Wili. and Polrtical. Legitimacy: a Gritical Exposition of Social. ConTRAC:Y THEORY in Hobres, Lockk, Rousseau, KANT, AND Hegei. (1982); Bazelon I, supra note 2 , at 388, 401-02; Delgado, supra note 2, at 14-15. Simply and roughly put, this is the theory that society can justifiably punish criminals for their crimes only to the extent that it has fulfilled its obligations to those criminals as members of the society. If society allows some of its members to be raised in a state of severe environmental deprivation, it has failed to fulfill its responsibilities to those members, and so it has undermined its right to punish them if they turn to crime as a result. To the extent that society has failed to fulfill these responsibilities, society and not the criminals is responsible for these crimes.

This rationale is also plagued by conceptual and practical difficulties. First, there is the question of what exactly are the terms of the social contract. Is it fair or realistic to expect a society such as ours to be able to guarantee a non-deprived or non-disadvantaged background to its members? Even if we answer in the affirmative, the argument may well prove too much. If it is assumed that all crime is caused, any criminal could argue that society did not meet its obligations to him, in that it did not provide an environment that did not result in criminal behavior. Backgrounds that are thought of as advantaged can also involve deprivations, and can lead to crime. The famous Leopold and Loeb murder case, in which two young men from wealthy and powerful families dispassionately and premeditatedly murdered an innocent child, is one in point. See C. Darrow, supra note 5, at 16-88. Nlso, one cannot argue that an individual's responsibility for a crime is eliminated if he was caused to commit it, and then consistently argue that society can be held responsible for its acts or failures to act if such acts or failures to act are themselves caused.

$\Lambda$ side from the conceptual difficulties confronting the social contract theory of excuse, the practical difficulties involved are enormous. It could potentially be used to excuse all or most criminals, which presents the formidable problem of deciding what is to be done with them. For an excellent discussion of these practical difficulties, see Morse, The Twilight of Welfare Criminology: A Reply to Judge Bazelon, 49 S. Cal.. L. Rkv. 1247, 1255-68 (1976).

20. The causal theory of excuse rationale for the MDEB position generally bases the mitigation of criminal responsibility claim on the mitigation of moral responsibility claim. See, e.g., Bazelon I, supra note 2, at 385-90 ("[N]o act should be made criminal if it is not viewed as immoral." Id. at 387.); Delgado, supra note 2 , at 11 n.12. For a discussion of lack of moral culpability as a foundation for legal excuses, see infra Section IV. 
him, at least to a considerable extent, to go wrong, whereas a more routine or fortunate past would not have done so. ${ }^{21}$

But if the non-disadvantaged person who commits a crime is not also caused to go wrong by his past, then determinism is false. If determinism were true, everyone's actions would be causally inevitable, the actions of the person from the good background as well as the actions of the person from the bad one, and the commonly drawn distinction between the cases with respect to responsibility would disappear. Determinism together with the causal theory of excuse would entail that no one is responsible for his actions. ${ }^{22}$ It would thus seem that the typical MDEB proponent is not or should not be a determinist.

\section{A. Libertarianism and the Argument from Moral Experience}

Assuming the MDEB proponent subscribes to the causal theory of excuse, but does not want to give up on responsibility altogether, she would have to insist that moral responsibility exists, and thus, that determinism is false. This position has been called libertarianism (not to be confused with the political philosophy of the same name). The basic contentions of libertarianism are that the causal theory of excuse is true, and that people are sometimes morally responsible for their actions; it would follow from these contentions that determinism is false.

Unfortunately for the MDEB proponent, libertarianism is an untenable position. ${ }^{23}$ At its heart is the causal theory of excuse, and this is the natural point of attack against the libertarian. A common approach in arguing against the causal theory of excuse is to claim that it is counterintuitive or not consistent with the greater part of our "moral experience."24

21. See authorities cited supra note 18.

22. This point has been recognized in some form by other writers. C.A. Campbell, for example, makes a similar point, see Campbell, supra note 18, at 115-16, but uses it to support libertarianism, a position which I try to refute. See infra text accompanying notes 29-51.

George Fletcher uses the same observation to argue against the recognition of prolonged social deprivation as an excusing condition, but bases his argument on basic libertarian principles, that is, on the causal theory of excuse and a rejection of determinism. See G. Fletcher, Rerhinking CrimiNAI. LAw 801 (1978). Fletcher rejects the claim that disadvantage causes crime, because he believes he would then have to grant that excessive advantage causes crime, and he fears that all of criminal responsibility would be threatened. Id. My argument against the recognition of prolonged social deprivation as an excusing condition is profoundly different, for I reject the causal theory of excuse, do not reject determinism, do not deny that disadvantage causes crime, and argue that causation does not threaten responsibility, but rather, makes it possible. See infra text accompanying notes $29-59$, and notes 57,78 .

23. The argument against libertarianism in the modern tradition traces back to David Hume. See D. Hume, $\Lambda$ InQuiry Conchrining Human Undersianding 90-111 (1955); see also Broad, supra note 5 (argues that libertarianism is self-evidently impossible, and also in effect that notion of moral responsibility can most likely have no application); Hobart, Free Will as Involving Determination and Inconceivable Without It, in FreE. WII.t. AND DFrrerminism, supra note 5, at 63 (argues that causation is required for, rather than incompatible with, free will).

24. See Moore, supra note 5, at 1144-48. 
Typically, the argument begins by distinguishing causation from compulsion, and claiming that beliefs and desires, or character traits, do not compel, though they may cause, behavior. ${ }^{25}$ As Michael Moore puts it, "I am caused, but not compelled, to go downtown by my desire to get a haircut." ${ }^{26}$ In essence, the argument is that:

We undeniably parcel out both praise and blame for actions and choices we know to be caused by factors external to the actor's free will. Our moral life is built upon our praising or blaming people when they help a friend, tell a bad joke, create a work of art, or write a clear and truthful essay about the excuses-even though we know at least some of the factors that caused these actions. ${ }^{27}$

This argument based on moral experience may have some intuitive appeal, but it is ultimately inconclusive and unpersuasive. The causal theory of excuse proponent ("causal theorist") would reply that responsibility is attributed for actions that were caused by factors external to the actor's free will, only because causation is not considered at the time of the responsibility attributions. The causal theorist would contend that drawing attention to causal origins of the actions would undermine the responsibility attributions. As an example, she might cite the fact that responsibility for wrongdoing is generally thought to be mitigated if the wrongdoing can be causally traced to social or environmental adversity during the wrongdoer's childhood. If her opponent replies that confirmation of the causal theory of excuse requires elimination rather than mitigation of responsibility in such cases, the causal theorist can counter that the causation in these cases is generally not thought to be absolute, that is, that the wrongdoing is not considered to have been inevitable given the wrongdoer's past, but only quite likely. The causal theorist would claim that if the wrongdoing were really inevitable given the wrongdoer's past, then people would not, or should not, hold him responsible at all. Thus, the causal theorist would claim that our moral experience actually supports her position.

The debate between the causal theorist and her opponent really comes down to a debate about the interpretation of the fundamental moral principle that an actor is responsible for his acts only if he could have chosen to do otherwise. ${ }^{28}$ The causal theorist contends that if the actor's choice

25. See, e.g., id. at 1129-32; Ayer, Freedom and Necessity, Polemic, Sept.-Oct. 1946, at 36, 40-44; Schlick, When Is a Man Responsible?, in FrEk. WILI. AND DerERMinisM, supra note 5, at $54,56-60$.

26. Moore, supra note 5, at 1130.

27. Id. at 1144-45.

28. See id. at 1142 . 
was causally inevitable and in principle predictable in advance, then he could not have chosen to do otherwise. Her opponent contends that if the actor's choice was caused but not compelled, then the actor could have chosen to do otherwise. To decide this issue by appeal to moral intuitions or practice will not be conclusive, because the relevant moral intuitions and practice are rather confused: Each side can muster some support from them. The causal theorist's contentions do have some appeal, but so does determinism, and if both positions are correct, then there is no responsibility for actions. This is in essence the free will-determinism problem, to which the libertarian responds by accepting the causal theory of excuse and rejecting determinism.

\section{B. The Conceptual Argument Against Libertarianism}

The argument against libertarianism that is based on our moral experience will simply degenerate into an argument about what our moral experience is or should be. The more definitive argument against it is a purely conceptual one, which demonstrates that libertarianism is an incoherent position. The libertarian claims that determinism is false, that it must be false in order for moral responsibility to exist, and that moral responsibility exists. She can be refuted by showing that to the extent that human actions are not causally related in the usual sense to their antecedents, their agents cannot be held responsible for them.

The conceptual argument against libertarianism proceeds as follows. Either an action is causally determined by past events or it is not. If the action is causally determined, then it is inevitable and in principle predictable. If it is not completely causally determined, this would mean that given past events, there was only some probability that it would occur; in other words, the action was not in principle completely predictable: To some extent at least it was a random occurrence or was due to chance. ${ }^{29}$ It is doubtful that anyone would want to claim that past events were totally irrelevant to the action's occurrence. Thus, the action was determined to some extent or order of probability, and beyond that it was due to chance. The libertarian would claim that to the extent that the action was determined, the agent cannot be held responsible for it. But to the extent that the action was not determined, it was due to chance. An agent cannot be held responsible for what was due to mere chance either. Thus, even if the action was not causally determined, the agent cannot be held responsible for it.

29. Libertarians in general will want to deny this causation-chance dichotomy; see, e.g., Foot, Free Will as Involving Determinism, in FrEE Wit.l. AND DrterminisM, supra note 5, at 95, 106-08. Libertarian responses to this dichotomy are discussed below. See infra text accompanying notes $39-51$. 
Why is it that pure chance cannot ground attributions of moral responsibility? To hold someone morally responsible for an action is to hold that the action redounds to his discredit. An action for which one is morally responsible reflects on his character. For this to be so the action has to be causally related to his character; to the extent that the action is due to chance, it is not a reflection on his character..$^{30}$ The major challenge for libertarians is to render intelligible some other relationship besides (ordinary) causation by which one's character can determine one's actions, or by which the authorship of actions can be attributed to an agent, and which on the libertarian's own terms does not interfere with the agent's freedom of choice or render attributions of moral responsibility problematic. What this task will come down to is to explain adequately a third source or origin of actions besides causation and chance. This is a hopeless task, as I will try to show after clarifying some key terms to be used in the demonstration.

\section{The Concept of Character and Related Terminology}

The term "character" is being used here in the sense in which it would be proper to say of a person that he was of good (or bad) character; it is meant to refer to moral character. A person's character in this sense may be described as the collection of many of his dispositions to act. It is a subpart, though a very significant subpart, of one's personality. It encompasses or involves certain traits, such as honesty, loyalty, kindness, fairness, ruthlessness, and greed, but not others, such as intelligence, sophistication, nervousness, and sense of humor. For the purposes of moral evaluation, it is the measure of a person.

It is extremely difficult if not impossible to provide a precise and complete explanation of the distinction between those traits or dispositions to act that are encompassed by one's character and those that are not. Such an explanation is not necessary for present purposes, however, since the concept of character is not being used in a special or technical sense; indeed, the plausibility of many of the claims I will make which incorporate the concept will derive largely from our ordinary understanding of and intuitions about it. A common sense understanding of the difference between character and non-character traits will be sufficient for an understanding of the related general points to be made below, and for drawing many important distinctions. ${ }^{31}$

30. See D. Hume, supra note 23, at 107-08.

31. The ordinary concept of character, or any general account of a concept that approximates it, will in all likelihood not suffice for deciding the hard cases involving the classification of traits as character or non-character traits. Such cases may well have to be decided by considering the moral theory in which the classifier embeds the concept, or by considering the purposes or goals for which 
Despite the preceding qualifications, there are some general features of character traits that can and should be noted. One's character traits are generally manifested by behavior that is within one's voluntary control, that is, by voluntary acts, traditionally defined as acts that are the product of exercises of the actor's will. ${ }^{32}$ One may be greedy, for example, but may choose not to act greedily on any particular occasion. A distinguishing feature of character traits is the degree to which their manifestation is subject to voluntary control. Ordinarily, a greedy person would be able to act as generously as he liked on any particular occasion if he had good enough reason to do so (for example, in order to get a job, or to prove a point). The manifestation of non-character traits is not ordinarily subject to voluntary control to such a degree. A stupid person, for example, does not have so much leeway to act stupidly or intelligently on any given occasion. And even an intelligent person, though he may choose to act stupidly if he has good enough reason to do so, cannot exhibit more intelligence than he has, however good a reason he might have to do so. If the manifestation of a trait is not at all subject to one's voluntary control, then it cannot be a character trait of that person. ${ }^{33}$ It is because one's character traits are generally manifested by behavior within one's voluntary control that behavior rooted in these traits can be directly influenced by reward and punishment, ${ }^{34}$ and character traits themselves may well be subject to such influence. $^{35}$

the classification is required. See, e.g., Brande, A Utilitarian Theory of Excuses, 78 PHIL. REv. 337, 358-59 (1969) (proposing in effect that decision on whether kleptomania is character trait should be based on whether it would maximize utility for moral system to excuse it).

32. See, e.g., O.W. Hol.MEs, supra note 9 , at $45-46$ (" $[\Lambda \mathrm{n}$ act $]$ is a muscular contraction, and something more. . . . The contraction of the muscles must be willed.").

For criticism of such traditional accounts of voluntary action, see G.E.M. ANSCOMBE, INTENTION 49-54 (2d ed. 1969); L. Writr(insinitin, Phil.osophical. Investrigations 159-62 (3d ed. 1958); Hart, Acts of Will and Responsibility, in PUNISHMENT AND RESPONSIBILITY, supra note 6, at 90; see also Monfi. PrNal. Conk, supra note $13, \S 2.01(2)$, which, perhaps because of the difficulties involved in trying to provide a direct positive account of voluntary action, defines a voluntary act only to the extent of excluding certain items from the category.

My intended usage of the term "voluntary" throughout this Note is neutral with respect to determinism. As I use the term, voluntary behavior is simply behavior that one chooses to do, or that is produced by one's beliefs and desires, in the normal way, whether or not these choices or beliefs and desires are themselves caused. See, e.g., Feinberg, supra note 5; Hart, supra note 13, at 29-30.

33. If a person were pathologically greedy, and thus could not help but act greedily on all relevant occasions, then even greed in such a case would not be a character trait.

34. This is not to suggest that only behavior rooted in character traits can be influenced by reward and punishment. Not all behavior can be directly influenced by reward and punishment in the same way that such behavior can be, however. The distinction is important, because it provides a key criterion for deciding whether punishment is appropriate.

35. For example, punishing one's greedy acts and rewarding one's generous ones may well decrease one's disposition to act greedily. See, e.g., 2 E. Sraub, Positrve Social Behavior and MokAt.rTy 140-45 (1979) (concludes that prosocial behavior can probably be increased by conditioning, and that "[clonditioning procedures are likely to lead to lasting behavior change or to behavior that is maintained without surveillance only when the external force exerted in the course of conditioning is perceived as relatively weak," id. at 141). Decreasing one's disposition to act unintelligently 
One's voluntary acts, if they involve any moral content at all (that is, if the acts themselves are commended or proscribed by morality), will generally reflect on one's character. Another way of putting this is to say that morally significant acts that are the acts of a rational agent and the result of a process of normal or undisturbed practical reasoning (the result of one's normal or undisturbed beliefs and desires), ${ }^{36}$ will generally reflect on the actor's character.

Providing a rigorous analysis of the expressions "determined by one's character" and "a reflection of one's character" is also a difficult matter, since these expressions involve the complex concept of causality, which virtually defies precise analysis. Some further explanation, though far short of such an analysis, should provide sufficient understanding for present purposes, however. To say that an action is determined by one's character is to say that one's having that character is the causal factor that would figure most prominently in an accurate explanation of how the action came about. This is not to say it is the only causal factor, or that it is the cause of the action. ${ }^{37}$ Causation always takes place in concrete circumstances; events are not causes in isolation, but rather, against a background of causal conditions, and causation depends as much on states or conditions as it does on events. Even in the case of a usually honest person who steals because she finds herself through no fault of her own in circumstances in which stealing is necessary for survival, the person's character is a causal condition of the person's stealing, but it is not the factor that would figure most prominently in a causal explanation of the event. This is not to say that the desperate person's stealing does not reflect on

is a different matter, however, since acting intelligently or unintelligently is not as subject to an unintelligent person's direct voluntary control: it would be totally ineffectual as well as inappropriate, for example, to punish a moron for failing to solve problems in integral calculus.

For more detailed discussions of the concepts of character and character traits, see R. BRANDT, Ethical. Throry 465-71 (1959); Brandt, Blameworthiness and Obligation, in Essays in MoraL Philosophy 3 ( $\Lambda$. Melden ed. 1958); Brandt, supra note 31, at 353-59.

36. See, e.g., Moore, supra note 5, at 1129-30. Practical reasoning is reasoning about what to do. One's acts are not the result of normal or undisturbed practical reasoning if one is not really capable of reasoning about what to do, or if one's "opportunity or capacity to follow the normal dictates of that reason is interfered with either by external factors (threats, natural necessity) or internal factors (extreme emotion or cravings)." Id. at 1130.

Moore uses the concept of practical reasoning to give an account of responsibility and excuse. His contention is that one can be responsible for an act only if it was the product of his undisturbed practical reasoning. Id. at 1131 . I cannot say I disagree with Moore on this, but I think that an account of responsibility in terms of character is conceptually more fundamental: if one can be responsible for an act only if it was the product of his undisturbed practical reasoning, this is because only under this condition can it reflect badly on his character.

37. Indeed, if we consider causes to be events, then strictly speaking a person's character could not be a cause at all because it is not an event. Even if we subscribe to event-causality, however, this would not preclude our considering a person's character to be the causal factor or condition that accounts for his action: we might, for example, cite the presence of oxygen as the "cause" of a fire if a match was struck in what we thought was a vacuum chamber. (The example is from H.L.A. HART \& A.M. Honorí, CaUSATION IN THE LAW 33 (1959).) 
her character, since, as was noted, her character is still a causal condition of her stealing. Her stealing indicates that though she is generally honest, she puts survival before honesty. Her stealing does not reflect on her character so as to indicate that she is a generally dishonest or morally defective person, however. Her stealing is not an expression or indication of her defective character. ${ }^{38}$

In general, if a person's character is a causal condition of his action, then I will consider the action to reflect on, or to be an expression of, his character. When I say that a person's action was caused by his character, I will mean that his character was a causal condition of the action.

\section{Responses to the Challenge for Libertarians}

Let us now return to the conceptual argument against libertarianism. In general terms, the difficulty which the libertarian confronts in trying to respond to the challenge to explain a third source of actions besides causation and chance is the following. Whatever the libertarian proposes as an alternative to causation and chance must be something which allows the actor to be properly held morally responsible for his morally objectionable actions. What an actor does is relevant to a moral evaluation of him only to the extent that it reflects on the sort of person he is. A person is good or bad directly because of what he is, and not directly because of what he does. A good person may perform a bad action through no fault of his own, and a bad person may do a good deed for which he deserves no praise. Actions are transient or fleeting things (though their effects may not be). The agent endures, however. Whether an action merits praise or blame, or reward or punishment, will depend on how it reflects on the agent, or on something enduring in the agent (which, following tradition, we are calling his "character"). ${ }^{30}$ Thus, if the action were done in the delirium of an unavoidable illness or injury, or under the influence of drugs not freely taken, the action might not reflect on the person's character, since it might not have been caused by it (or the action might not have been determined by the person's character, since his character might not figure prominently in any accurate explanation of the action). Similarly, the mitigated responsibility that attaches to unintentional actions and to actions done under duress or coercion is due to the fact that the agent's character is not as determinative of such actions. ${ }^{40}$

38. Defectiveness here is relative to the societal norm or average as to what is to be expected of a person: $\Lambda$ person's character can be less commendable than a saint's without being defective. $A$ generally honest person would be morally responsible for a dishonest act, however, if in acting dishonestly she did not measure up to the applicable moral standards.

39. Hume makes essentially the same point in D. HumE, supra note 23, at 107.

40. See, e.g., Monk. Prnal. Codf, supra note $13, \S 2.02$ (providing for four levels of culpability 
If an action is caused or determined by the agent's character, it is clear that it reflects on his character: It was his character or some aspect of it that helped bring the action about. If an action is due to chance, it is clear that it does not reflect on the agent's character. ${ }^{41}$ The challenge for the libertarian is to elucidate some relationship between an agent's action and his character (or between the action and the agent) besides causation by which the former can reflect on the latter. A little thought should reveal the difficulty in even conceptualizing such a relationship. Indeed, it seems an impossible task, and no known libertarian has yet to succeed at it. To illustrate the difficulties involved, I will discuss two of the main approaches taken in response to this challenge for libertarians, as exemplified in the work of two competent modern spokesmen for the position.

\section{Choice and Creative Activity}

What is probably the most common general approach taken in response to the challenge for libertarians has been used notably by C.A. Campbell. ${ }^{42}$ Campbell argues that though moral responsibility is incompatible with determinism, the concept of a "contra-causal" (that is, incompatible with causation) freedom which could ground moral responsibility is intelligible. He considers the applicability of attributions of moral responsibility to be limited to situations in which duty is opposed by strongest desire. Campbell claims that free will transcends character when an agent chooses to act according to duty and against his strongest desire, and that such choices arise by creative activity, which can be apprehended only from inner or private experience or participation. ${ }^{43}$ "Creative activity" is in effect what Campbell offers as a third alternative to causation and chance as a potential source or origin of actions.

One mistake Campbell makes is that he incorrectly interprets the concept of "character." According to his view, if a person acts against his strongest desire and in accordance with duty, he is transcending his character. But one's character is not represented in this case by one's strongest desire. An impeccable moral character would actually be one which led a person always to act according to duty even when duty is opposed by strongest desire. A person with such a character who acts in this way is acting in character, not transcending it. The same would hold for the less

ranging from "purposely" to "negligently" in descending order), $\$ 2.09$ (providing for affirmative defense of duress).

41. If the action is causally determined in the circumstances by the agent's character only to some extent or order of probability, and is due to some extent to chance, then only to the extent that it is determined by the agent's character will the action reflect on it.

42. Campbell, supra note 18.

43. Id. at $131-32$. 
morally perfect agent: his lower percentage of morally correct performances would reflect on his character as well.

The more fundamental problem for Campbell is that he has not made intelligible another way for us to understand what it might mean for someone to act out of character if it did not mean that his action was due to chance. Suppose agent $\mathrm{A}$ chooses to do $\mathrm{X}$ in a morally relevant situation (that is, when duty is opposed by strongest desire), and that his doing $\mathrm{X}$ is "out of" character in the sense that it is not caused by his character. What does it mean to say that A's choosing to do X is the result of "creative activity"? Campbell claims this question must be addressed from an introspective standpoint, and his answer is that he himself, as an agent in morally relevant situations, experiences both the course dictated by duty and by strongest desire to be open possibilities. In such situations, he feels that he could either give in to his strongest desire or by an effort of will act in accordance with duty: The choice is not causally determined but is a result of creative activity on his part. It is still clearly his choice, though it is not caused by his character and prior events. ${ }^{44}$

This is another of Campbell's fundamental mistakes. What he experiences in these situations is not really relevant. He may feel free to choose, though his choice is causally determined. Campbell actually acknowledges this but believes that even if the feeling is wrong, it is enough to render meaningful the idea of an act that can be attributed to the self, and yet is not an expression of the self's character. ${ }^{45} \mathrm{He}$ is clearly mistaken. This would be to say that an idea is intelligible just because it seems intelligible. Whether the choice to follow duty or strongest desire is open or not, the notion of an action's being out of (uncaused by) character and yet attributable to the self in a sense sufficient to ground ascriptions of responsibility, remains unintelligible. If the choice is not open, then the action is caused and is an expression of character (unless it has another cause and so is not attributable to the self). If the choice is open, nothing has been offered as a real alternative to the conclusion that it is due to chance. What does it mean to say that an agent "creates" a choice? All that can be inferred from what Campbell writes is that it means that the created choice is not causally determined by the agent's character, yet is not due to chance. This answer does no more than beg the question. If the choice is not in some way the product of something enduring in the agent, then it cannot reflect on something enduring in him. If it does not reflect on something enduring in him (his "character"), then he cannot be held morally responsible for it. It may still be the agent's "choice" in the sense 
that he "makes" it, that is, he does the action, not someone else, but this fact cannot provide the foundation for proper attributions of moral responsibility: He "does" the action in this sense even when the action's occurrence is due to chance.

Campbell also runs into a problem with his notion of creative activity that all libertarians encounter when the alternative relationship between character (or agent) and action that they offer itself involves a sort of action, as "creative activity" apparently does. This problem comes to light when one inquires into the origin of this "creative activity." It seems clear that according to Campbell's position, a person can be held responsible for acting as he does because he can be held responsible for "creating" the choice to act as he does. But, as has been explained, this creative activity, assuming it is a sort of action, must reflect on the agent or on something enduring in him (his "character") for it to redound to his credit or discredit. Campbell cannot rely on causation as the basis for the creative activity's reflecting on the agent or his character; rather, he must posit some further creative activity as the basis for the original creative activity's reflecting on the agent or his character. But the agent will also have to be responsible for this further creative activity, and thus an infinite regress is generated.

It should also be noted that for similar reasons it would not avail Campbell to fall back on the old libertarian notion that in "creating" a moral choice, the agent is "creating" his self or his character. This idea is also incoherent. Only a person's creator, or his heredity and environment, and perhaps some element of chance as well, are the "authors" of that person or his character. ${ }^{48}$ To claim otherwise would involve one in an infinite regress like the one just explained. Anything a person does to "remake" his character is an action of his, and as such, must reflect on something enduring in him for it to redound to his credit or discredit, whether we call this enduring element a part of his character, or whatever. For the libertarian this would require, as was shown, that this "creative" action in turn be created, and the libertarian would have to go on in this way with no end in sight. Thus, it should be clear that the libertarian cannot vindicate responsibility by shifting her focus from moral choice to character,

46. An extreme or radical libertarian position would actually be inconsistent with the MDEB position. Some have contended that people are ultimately responsible (i.e., responsible in a libertarian sense) for their choices regardless of their backgrounds. See, e.g., Branden, Free Will, Moral Responsibility and the Law, 42 S. CAl.. L. REv. 264, 278 (1969) (criminal from bad background can be held accountable because as child, he "allow[ed] himself to be shaped by his environment"); Sartre, Being and Doing: Freedom, in Frre: WII.I. AND Drirerminism, supra note 5, at 174, 179 ("Under no circumstances can the past in any way by itself produce an act; . . . the indispensable and fundamental condition of all action is the freedom of the acting being."). 
since the same problems she faces with respect to the former will confront her with respect to the latter.

In sum, Campbell has not elucidated any other relationship between the agent's character and his moral choices besides causation that would enable these choices to reflect on his character. In the absence of such a relationship between the agent's character and his choices, his creating them becomes just a matter of chance, and how he feels about the matter is irrelevant. Campbell has failed to provide another possible derivation of our choices besides causation and chance. He has failed to meet the fundamental challenge for libertarians.

\section{Agent Causation}

Another approach libertarians have taken in trying to provide a third alternative to (ordinary) causation and chance as a source of actions is to claim the existence of another sort of causation, called agent-causation. The main spokesmen for this view have been Roderick M. Chisholm and Richard Taylor. ${ }^{47}$ I will discuss Taylor's version of the theory, but Chisholm's account is afflicted with essentially the same fundamental problems. According to Taylor, "men ... are sometimes . . . selfdetermining beings; that is, beings which are sometimes the causes of their own behavior." ${ }^{48}$ He claims that for something to count as an act, it must have been caused by the agent, whether he was caused in the ordinary sense to do it or not. If he was not caused in the ordinary sense to do it, then it was a free act. It must be stressed that agent-causation is radically different from ordinary causation. It is not a relation between events, but between a substance (the agent), and an event (his movement or action). ${ }^{49}$ Agent-causation does not entail that the agent's acts of will, or desires and beliefs, bring about his bodily movements, or that neurological events do. When a person agent-causes a bodily movement, it is simply the agent himself who brings it about, without having to do anything else in order to do it.

Agent-causationists make it clear what agent-causation is not, that is, that it is not ordinary causation. The problem is that they can offer no positive explanation of it that renders it anything less than utterly mysterious. In attempting to explain agent-causation, agent-causationists are reduced either to analogizing it to ordinary causation, to which it was supposed to be an alternative, or to claiming that it is a primitive concept

47. See, e.g., R. Tayior, Acrion and Purpose (1966); R. 'Taylor, Metaphysics 33-53 (1963); Chisholm, The Agent as Cause, in Acrion Throry 199 (M. Brand \& D. Walton eds. 1976); Chisholm, Freedom and Action, in Frekodom AND Detreminism 11 (K. Lehrer ed. 1966).

48. R. TaYiok, Mriraphysics 50 (1963).

49. Id. at 51 . 
which is unanalyzable, which is totally unsatisfactory and unhelpful. The agent-causationist's claim is actually similar to the Campbellian claim that a person "creates" his choices, except that for the agent-causationist the choices drop out of the equation, and the person simply "creates" the movement; the problems and questions are thus similar to those encountered in considering Campbell's position. The agent-causationist has to explain how the agent fits in the causal order. When the agent acts freely, he is not caused to agent-cause his movements. But how or why did this agent-causing come about? By definition, it cannot have been caused in the ordinary sense by his reasons, motives, and beliefs. No explanation has been given of how such uncaused agent-causings can reflect on the agent so that he can properly be held morally responsible for his actions. Also, the agent-causationist does not want to deny that acts can be rational. This leaves him with another mystery he cannot adequately explain: how reasons can be non-causally related to agent-causings or acts so as to make acts rational. To simply say reasons are related to actions noncausally, or in some special different causal way, does not begin to help us understand why agent-causings or actions take place. ${ }^{50}$

Thus, both of the main libertarian responses to the challenge to explain a third source of actions besides causation and chance that have been considered are fundamentally flawed and unsatisfactory. The flaws illustrate the difficulties in general that confront the libertarian in her attempt to respond to this challenge. ${ }^{51}$ In the absence of a better response, the libertarian position does not seem to be even intelligible, let alone tenable.

\section{Consequences for the MDEB Proponent}

Let us return to the MDEB proponent who, it was assumed, subscribed to the causal theory of excuse. One way for her to avoid giving up responsibility altogether was to adopt libertarianism. ${ }^{52}$ But libertarianism, as has been shown, seems to be an incoherent position. She has other alternatives to abandoning the concept of responsibility, however. One alternative is to give up moral responsibility without giving up criminal responsibility. ${ }^{63}$

50. For a more thorough and definitive assessment of agent-causation, which guided the discussion here, see Thalberg, How Does Agent Causality Work?, in ACTION Throry, supra note 47, at 213. For a more recent discussion of agent-causation, see P. VAN INWAGEN, AN ESSAY ON FREE Wil.1. 135-52 (1983).

51. See, e.g., Chisholm, Human Freedom and the Self, in Free. Wil. 24, 32-35 (G. Watson ed. 1982) (notion of "inclination" or "influence" is offered as alternative to causation and pure chance); P. vaN INWAGiN, supra note 50, at 150 (libertarian author concedes that his position is "puzzling," for reasons similar or related to those presented supra text accompanying notes 29-51).

52. See supra text accompanying notes 22-23.

53. This seems to be an approach adopted in the Monfi. Prinal. Cone, supra note $13, \$ 2.01$ comment 1 at 215. The Code cites Hart, supra note 32, and H. PACKER, supra note 1, to support the assertion that " $t]$ he term 'voluntary' as used in this section does not inject into the criminal law 
Even if determinism is true, so long as criminal punishment can discourage behavior, a system of criminal law imposing punishments to secure certain socially desired standards of behavior would still make sense. Though logic may not require it, however, there is, as was noted, a practical, as well as a widely felt moral, value in incorporating morality to some extent into our criminal law, and in seeing to it that criminal responsibility does not diverge too greatly from moral responsibility. ${ }^{54}$ Also, abandoning moral responsibility should not have great appeal to the MDEB proponent, since her contention that an adverse early social background mitigates criminal responsibility was presumably based on her contention that it mitigated moral responsibility. ${ }^{\mathrm{BS}}$

I believe that a better alternative than giving up moral responsibility is to give up the idea that determinism is incompatible with moral responsibility, which would be to adopt a view known as compatibilism. This would involve giving up the causal theory of excuse, and thus, the MDEB position itself, which by assumption was based on the causal theory of excuse. The version of compatibilism I advocate claims that an agent can properly be held morally responsible for his actions to the extent and only to the extent that they reflect badly on his character. ${ }^{56}$ Thus, if an action

questions about determinism and free will." Id. I think that the approaches to determinism exemplified in these sources leave something to be desired. The Hart essay cited does not directly address the issue of determinism; it merely criticizes a traditional account of the criminal law's concept of a voluntary act, and offers an alternative account. See supra note 32. Hart does, however, directly address determinism in another essay in the same cited collection. See Hart, supra note 13. Hart's defense of the voluntary act requirement against determinism in the latter essay concerns itself only with criminal responsibility, and not at all with moral responsibility. See id. at 53 . This is a major difference between Hart's compatibilism and the compatibilist account I will develop presently. There is no need to keep morality and moral responsibility out of the criminal law in order to avoid problems posed by determinism, as I will try to show.

Packer, on the other hand, contends that determinism is not really at issue in the criminal law, because "[t]he idea of free will in relation to conduct is not, in the legal system, a statement of fact, but rather a value preference... [T]he law treats man's conduct as autonomous and willed, not because it is, but because it is desirable to proceed as if it were." H. PACKER, supra note 1, at 74-75. In effect, Packer is asserting that it is perfectly all right for one of the law's fundamental principles to be based on mere make-believe, fantasy, or wishful thinking. Surely, this is not a satisfactory way for the criminal law to deal with the free will-determinism problem, unless there is no better alternative. (Cf. Wolf, The Importance of Free Will, XC Mind 386, 404-05 (1981) (pointing out that being mistaken in thinking we are free and responsible beings would be disturbing, even if we were not at fault for, or irrational in, thinking we are free and responsible).) $\Lambda$ main purpose of this Note is to show that there is a better alternative.

54. See supra Section II.

55. See supra text accompanying notes $19-20$, and note 20 .

56. $C f$. D. HumF, supra note 23 , at 108 (" $[A]$ ctions are objects of our moral sentiment so far only as they are indications of the internal character . . . ."); Brandt, supra note 31, at 355 ("[A]n action is morally excused if it manifests no defect of character, or, in other words . . . an agent of an action is morally blameworthy on account of it only if it manifests a defect of character."). Brandt, however, does not dispute the claim that an adverse early social background can mitigate responsibility; indeed, he seems to endorse it on sympathy grounds. See R. BRANDT, supra note 35 , at 474.

I have presented what I consider to be the core of the compatibilist conception of responsibility. This account in terms of character is sufficient to make the fundamental compatibilist point, which is all that is needed to specify the general approach to determinism that I advocate for the criminal law. 
is a moral wrong, and it was determined by the agent's character, in the sense that his character would be the predominant causal factor in an accurate explanation of the action, then he generally would be morally responsible for it. ${ }^{57}$ This position, while compatible with determinism, would not commit one to it. However, since I want to claim that people are morally responsible for some of their actions (because these actions reflect badly on their characters), I will interpret the position to commit one to the claim that a person's actions are causally determined by his character to some extent or order of probability beyond what chance would dictate.

It clearly follows from this view that one's past is irrelevant to the assessment of his moral responsibility for a wrong he committed: All that is relevant is the extent to which his character was causally responsible for the wrong, or in other words, the extent to which the wrong was due to

Contemporary analytic philosophers of the compatibilist persuasion have tried to present accounts of responsibility that are more detailed or specific, and that may be more informative with respect to application to particular cases. Though they do not all speak in terms of character, it is my belief that what they are doing in effect is spelling out conditions for when actions reflect badly on their agents' characters. See, e.g., Dworkin, Acting Freely, 4 Noûs 367 (1970); Frankfurt, Freedom of the Will and the Concept of a Person, in Morai. Responsibiziry, supra note 7, at 65; Watson, Free Agency, in FreE: Wil.t., supra note 51, at 96; see also Dworkin, Autonomy and Behavior Control, 6 Hastings Center Rep., Feb. 1976, at 23.

Compatibilism is not an uncontroversial position; a sustained recent criticism of it can be found in P. VAN INWAGEN, supra note 50. Actually, I would agree with the claim that our traditional conception of moral responsibility is not a compatibilist one. But I believe that our traditional conception of moral responsibility can have no application, since an incompatibilist or libertarian conception does not make sense. Thus, I believe that our traditional concept of responsibility must be reconstructed into a compatibilist one. The same would apply to many responsibility-related concepts, such as the concepts of goodness or badness as applied to people, and the concepts of praiseworthiness and desert in general. This compatibilist conception of responsibility can, I think, be used to provide a rational basis for punishment, and for some of the positive and negative feelings and attitudes we have towards other people because of their behavior. (P.F. Strawson calls these attitudes and feelings "reactive," and points out that they are closely related to the concepts of freedom and responsibility, and are an important part of our moral lives. See Strawson, Freedom and Resentment, in Frex. Wil., supra note 51, at 59.) This reconstructed concept of responsibility cannot, however, sustain a classic retributive theory of punishment, or Western religious beliefs in an after-life of eternal reward or punishment. Nor can it fully justify the profound feelings of resentment or desire for vengeance we may feel towards other people as a result of their actions. The aim of this reconstruction project is to save as much as possible of the traditional concept of responsibility and related concepts, and to discard, or at least put us on notice about, whatever cannot be rationally maintained. I believe the project is important and worthwhile, but these are matters that must be pursued in detail elsewhere.

57. George Fletcher has also given an account of responsibility in terms of the relation between a person's actions and his character, and has discussed the MDEB position in these terms. See G. F1.ErChr. supra note 22, at 798-802. Fletcher maintains that criminal responsibility should require a wrongful act that is attributable to the character of the actor rather than to circumstances. Id. at $799-801$. His basic insight is sound, but his conception of character and its relation to actions is confused. Most acts are attributable to their agent's character and the circumstances in which he finds himself. Fletcher claims that "[t]he distinguishing feature of excusing conditions is that they preclude an inference from the act to the actor's character." Id. at 799. This is simply wrong. One who steals food as the only alternative to starving, for example, may be acting under duress or necessity, but is still revealing something about her character: Her instinct for survival is stronger than her honesty or aversion to theft. The excuse does not at all "represent a limited, temporal distortion of the actor's character," as Fletcher claims. Id. at 802 . This will be discussed further, infra note 78 . 
his bad character. A bad character is simply one that tends to produce bad actions, as defined by the moral theory we are using; a good character is similarly explained. A good or bad person from a moral perspective would then simply be one with a good or bad character. The sort of character a person has is relevant to assessing his moral responsibility for an action, but not how he came to have that character. The person is not being held responsible for his character, and his character would be as bad however he came to have it. ${ }^{68} \mathrm{His}$ past might be relevant in helping us to understand the nature of the defects in his character, and in helping us to determine how they might be corrected. But though his past may have produced the defects, it would not diminish them. It may in fact turn out that a person who is bad as a result of being raised in a bad environment may be easier to "fix" than one whose corrupt character was due mostly to genetic factors. This might to some extent support the common intuition that people from bad backgrounds who commit crimes should be treated more leniently than criminals without such a past: Less drastic corrective measures may be required for the former. Whether this is so is of course an empirical matter.

The incoherence of the libertarian conception of moral responsibility arises from the fact that it requires not only authorship of the action, but also, in a sense, authorship of one's self, or of one's character. As was shown, this requirement is unintelligible because it leads to an infinite regress. ${ }^{59}$ The way out of this regress is simply to drop the second-order authorship requirement, which is what has been done here. Under the compatibilist scheme being advocated, the concept of moral responsibility that emerges is one related strictly to the moral evaluation of agents in terms of their character-determined tendencies to produce good and bad actions. In simplest terms, one might say that the main point of this sort of compatibilism is that there can still be good and bad people in this sense, even if determinism is true.

Thus, moral responsibility in this compatibilist sense can still be an element of criminal responsibility, thereby allowing morality to be incorporated into our criminal law to the extent that competing values and goals permit, whether determinism is true or not.

58. I do not mean to suggest here that one's character is not susceptible to change, nor that one cannot be responsible for changing one's character in a compatibilist sense. For one to be responsible for such changes, however, one's character must be causally related to them, so that the changes themselves reflect on the person's character. The point is that the person cannot properly be held ultimately responsible for the "flexibility" or other traits that made the changes possible, because the ultimate origins of one's character will be heredity, environment, and perhaps some degree of chance.

59. See supra text accompanying note 46. 


\section{ResponsibILITy AND Excuse}

The consideration of whether severe environmental deprivation mitigates or eliminates responsibility, has led to a general principle about responsibility, namely, that one is morally responsible for all and only those acts which reflect badly on one's character. This responsibility principle can provide a theoretical foundation for the recognized legal excuses, and a plausible criterion for deciding whether particular circumstances or situations constitute a legal excuse, either under an already recognized excuse category, or under some new category worthy of recognition.

The excuse categories that are characteristic of Anglo-American criminal law are mistake, accident, provocation, insanity, and duress. ${ }^{60}$ While moral and legal responsibility do not completely coincide in our legal system, it seems clear that lack of moral culpability can be considered the primary basis for the recognized legal excuses. ${ }^{61,62}$ Acts performed subject to one of these excuses are acts that do not reflect badly, or as badly, on the actor's character. ${ }^{63}$

Consider the defense of insanity, for example. The controversy on this topic has centered more on problems of definition and implementation than on disagreements of principle. ${ }^{64}$ If a person kills because of his severely distorted perceptions (for example, he thought that God ordered him to kill, ${ }^{65}$ or that his victim was a mad alien about to destroy the

60. See Hart, supra note 13, at 31; Moore, supra note 5, at 1095-99 (more detailed survey of legal excuses); Monfi. Penal. Cont, supra note 13, $\$ \$ 2.04,2.08,2.09,4.01-.03,4.10$; Monfl. Prnat. Conf: and Commintakiks $\S 210.3(1)(b)$ \& comment 5 (Official Draft and Revised Comments 1980).

61. This is not to suggest that no remotely plausible utilitarian theory of excuses is possible. See, e.g., Brandt, supra note 31. There are well-recognized problems associated with utilitarian theories of punishment and excuse, however. See, e.g., id.; Hart, supra note 10; Hart, supra note 13.

62. Some of the mitigating factors set forth in statutes dealing with sentencing in capital cases are analogous to some of the legal excuses. See, e.g., Cor.o. Rrv. SrA'r. \$ 16-11-103(5) (1986) (cxamples of mitigating factors listed under statute are significant impairment of defendant's capacity to appreciate wrongfulness of his conduct or to conform to law's requirements; unusual and substantial duress; defendani's good faith though mistaken belief that his conduct was morally justified).

63. The plausibility of this explanation of legal excuses is recognized in, for example, $G$. Fl.Frchkr, supra note 22, at 798-801; Fletcher, The Individualization of Fixcusing Conditions, 47 S. Cal.. L. Rrv. 1269, 1271 (1974).

64. See, e.g., Royal. Comm'n on Caprtal. Punishment 1949-1953 Rrporr (1953):

It has for centuries been recognised that, if a person was, at the time of his unlawful act, mentally so disordered that it would be unreasonable to impute guilt to him, he ought not to be held liable to conviction and punishment under the criminal law. Views have changed and opinions have differed, as they differ now, about the standards to be applied in deciding whether an individual should be exempted from criminal responsibility for this reason; but the principle has been accepted without question.

Id. para. 278.

Even some who argue that the insanity defense should be abolished do so on the grounds that the mens rea or voluntary act requirements make it unnecessary, not on the grounds that mental illness should never eliminate responsibility. See, e.g., Goldstein \& Katz, Abolish the "Insanity Defense"-Why Not?, 72 Yal.t. L.J. 853, 862-63, 872 (1963).

65. Cf. People v. Skinner, 39 Cal. 3d 765, 704 P.2d 752, 217 Cal. Rptr. 685 (1985) (murder 
earth), or because his thought processes are so disturbed that he could not be considered a rational agent at all ${ }^{66}$ (for example, he has a brain tumor that produces irresistible urges to commit violence, ${ }^{67}$ or that so distorts his logical sense as to render his behavior totally inscrutable), then his killing would not reflect badly on his character. ${ }^{68}$ The killing in such cases would not be determined by traits that are generally manifested by voluntary behavior ${ }^{6 \theta}$ which can be directly influenced by reward and punishment or praise and blame, or the killing would not be the result of a process of normal or undisturbed practical reasoning. ${ }^{70}$ Punishing a person for killing in such circumstances would not have any positive effect on his behavior or character, and would offend the moral sense of most people. In a distorted perception case, the actor may be capable of reasoning about what to do and of voluntary action, thus qualifying as a rational agent, but he is afflicted by delusions or hallucinations that disturb or interfere with his practical reasoning. ${ }^{71}$ Thus, his behavior may reflect on his character, but in the examples given, it would not reflect badly on his character: Given his perceptions, his behavior was not morally objectionable, that is, he lacked the requisite evil intent or mens rea. In a case in which the actor does not qualify as a rational agent at all, at least with respect to the particular crime at issue, his crime would not reflect on his character at all: Any inference to character would be blocked because he lacked the capacity to reason about what to do and to act voluntarily. ${ }^{72}$

conviction reversed on grounds of insanity because defendant thought killing his wife was "sanctified" by God's will and desire).

66. See Moore, supra note 5, at 1137-39.

67. See Regina v. Charlson, [1955] 1 All E.R. 859 (devoted father who attacked and seriously harmed ten year old son, found not guilty, where evidence indicated possibility that he was suffering from brain tumor that made his behavior uncontrollable).

68. Cf. Feinberg, What Is So Special About Mental Illness?, in Doing ANd Deserving, supra note 5, at 272, 276 (man who kills because of insane delusion is excused so long as "if the facts were as he falsely supposed them to be, his act would have been innocent").

69. The notion of voluntariness that is being used throughout this Note is a compatibilist one. See supra note 32.

70. See supra text accompanying notes 32-36, and note 36; see also Moore, supra note 5, at 1129-30, 1137-39.

71. See Mayock v. Martin, 157 Conn. 56, 245 ^.2d 574 (1968), cert. denied, 393 U.S. 1111 (1969) (discussed infra note 72).

72. One might want to restrict the insanity defense to cases in which the accused is not a rational agent, thus making it strictly a status defense. See, e.g., Moore, supra note 5, at 1137-39. If an actor is afflicted with a mental disease or defect that renders him not a rational agent, then he lacks the status to make him a fit object for punishment, as do an infant, a tree, or a stone: All lack the capacity to reason practically (i.e., about what to do) and act accordingly.

The distorted perception cases, however, do not fit so neatly into this category, since distorted perceptions alone would not necessarily render one unable to reason practically and act accordingly. To exclude such cases from the insanity category is counterintuitive, and would not seem to serve any useful purpose. See, for example, Mayock $v$. Martin, in which the trial court's finding that plaintiff suffered from a mental disease that justified his confinement in a mental hospital for over twenty years was upheld, though there was every indication that plaintiff could and did reason practically and acted accordingly. The only basis for his confinement was the danger to him (but not to others) 
The choice, interpretation, and implementation of a particular standard for the insanity defense can be informed and enhanced by the general responsibility standard proposed here. This general standard as applied to the insanity context would entail that if one's mental illness or defect prevents an inference from his act to a defective character, then he is not responsible for his act. Indeed, it may well be this standard in some form that is often applied by jurors and experts. ${ }^{73}$

The proposed responsibility principle can be similarly applied to cases involving novel or controversial factual circumstances, such as battered spouse's syndrome, war veteran's syndrome, pre-menstrual syndrome, and brainwashing. The "rotten social background"74 excuse is in this more controversial category, and to the extent that it refers to the influence of an adverse early social background as discussed above, it has already been evaluated using this responsibility principle. ${ }^{75}$ Another sort of case was discussed, however, which may also be included under the "rotten social background" heading, but which yields a different result upon application of the proposed principle. This is the sort of case in which one's adverse social background persists into the present, and her present or immediate adverse "background" or circumstances substantially influence her behavior, ${ }^{76}$ as in the case of a basically honest person who steals only because she finds herself through no fault of her own in circumstances in which

posed by his unusual and persistent religious beliefs which had led him to remove his right eye and hand many years before. Id. at $60-61,245 \Lambda .2 \mathrm{~d}$ at $576-77$.

73. The proposed standard would tend to restrict the insanity defense to severely disturbed people, which is probably what many juries and experts do regardless of the applicable legal standard. See, e.g., Moore, supra note 5, at 1137-39 (citing M. MOORF, Law and Psychiatry: Reirinking; 'THE: Relationship 217-45 (1984)); Royal. Comm'n on Caprral. Punishmentr 1949-1953 Rrport paras. 293, 322 (1953) (" "However much you charge a jury as to the M'Naghten Rules or any other test, the question they would put to themselves when they retire is-'Is this man mad or is he not?"." Id. para. 322 (quoting Lord Cooper).); Reid, The Working of the New Hampshire Doctrine of Criminal Insanity, 15 U. Miamı L. Rkv. 14, 18-19 (1960) (despite fact that New Hampshire doctrine of insanity has wider scope, "[i]t seems to be virtually a policy that a person will not be certified as criminally insane unless he is a psychotic"); see also $\Lambda$. Goidsrrin, Thk Insanrty Dkfensk 59-62 (1967) (indicating "quite widespread feeling among psychiatrists that all psychotics should be regarded as insane," id. at 60-61); Waelder, Psychiatry and the Problem of Criminal Responsibility, 101 U. PA. L. Rsv. 378, 384 (1952).

An example of a form the proposed standard might take as applied by jurors and experts is the following: $\Lambda$ offender should be excused if his offense indicates, not that he is bad, but that he is crazy.

74. This phrase was used in Delgado, supra note 2, wherein it was stated that the phrase "seems to have been coined by the trial judge in United States $v$. Alexander and was later used by Judge Bazelon to describe conditions of socioeconomic and environmental adversity." Id. at 11 n.11 (citing United States v. Alexander, 471 F.2d 923, 961 (D.C. Cir. 1973) (Bazelon, C.J., dissenting)).

75. See supra text accompanying notes 55-59.

76. Actually, it might be clearer and more accurate to describe such cases as essentially involving adverse present circumstances and not background at all. However, by hypothesis it is the adverse social background that persists and becomes the relevant part of the person's present circumstances, thereby making it likely that, rightly or wrongly, such a case will be thought of as a social background case. 
stealing is necessary for survival. ${ }^{77}$ As was noted, in such a case the person's stealing does not reflect badly on her character, since the stealing was due to her circumstances, not to a defective character. ${ }^{78,79}$ If a person's crime is virtually forced on her by her present circumstances, then these circumstances may be considered a valid excusing condition within the duress category or an extension of it. ${ }^{80}$ Whether this relationship to character, which is a requirement for moral responsibility, should also be made a requirement for criminal responsibility in such a case of duress, and in general, would depend in part on other factors. Among these other factors would be administrative and evidentiary difficulties, and the degree of social utility that would be gained or sacrificed. ${ }^{\mathbf{8 1}}$ Aside from such considerations, however, increasing the coincidence of law and morality is to be desired.

\section{ConClusion}

The notion that one's past or early background can mitigate responsibility for one's later actions was attacked by arguing against libertarianism, a philosophical position with which it is generally associated. This argument demonstrated that causation was necessary for, rather than destructive of, moral responsibility, and suggested the principle that one is morally responsible for all and only those acts which reflect badly on one's character. This responsibilty principle was also proposed as a rationale

77. See supra text accompanying notes $37-38$, and notes 38,57 ; $c$. Everett v. United States, 336 F.2d 979, 984-87 (D.C. Cir. 1964) (Wright, J., dissenting) (defendant claimed he was poor and stole to provide medical care for his pregnant wife).

78. Fletcher also distinguishes such cases from those in which one's past or early background has had enduring effects on a person which result much later in his turning to crime. Fletcher's distinction, however, is based on his characterization of the present social background case as involving only a "limited, temporal distortion" of the person's character. G. FlETCHER, supra note 22, at 802. As previously explained, supra note 57 , such cases usually do not involve any distortion of the person's character; rather, the person's stealing in her desperate circumstances merely indicates that she values survival more than honesty. Also, the limited temporal duration is not the salient distinction. One can be entrenched for a lifetime in circumstances that require stealing for survival; the persistent pattern of stealing would not eliminate the rationale for excusing it.

79. Another type of "rotten social background" case that should be noted is one in which a person's past produces a condition (e.g., psychosis, or distorted perception, including the variety that falls short of mental illness) that both leads to wrongful conduct and also mitigates or eliminates responsibility for that conduct. In such a case, one's past may be said to indirectly mitigate responsibility, but the real mitigating factor would be the present condition that removes or diminishes the indication of a bad character.

80. See Hart, supra note 13, at 51. Actually, in such extreme circumstances a case of duress might become one of necessity.

It should also be noted that a person that acts under duress is not necessarily totally absolved of responsibility. For example, a soldier that gives catastrophically damaging information to the enemy under torture might be considered responsible to some degree despite the duress: we might believe that a person of average character would have resisted the torture for a longer time. The responsibility determination in such cases would depend on how much was at stake and on the degree of duress.

81. It may well be better to take account of the mitigation of responsibility involved in such cases at the sentencing rather than the trial phase. See supra note 3. 
for legal excuses. Since moral responsibility is compatible with determinism according to this principle, the untenability of libertarianism is no obstacle to retaining a place for moral responsibility in our criminal law.

Libertarianism is a significant part of the fabric of Western thought, and abandoning it will involve abandoning or seriously modifying other related and important concepts. ${ }^{82}$ Some might not be entirely satisfied with the compatibilist conceptions that can be offered as replacements. It is better to learn to live with these replacements, however, than to hold on to an incoherent philosophical tradition. It is especially important for those making important societal decisions about punishment and responsibility, including legislators, judges, parole and pardon boards, prosecutors, and juries, to discard concepts and ideas bearing on these topics that simply do not make sense. This can only help to promote more rational and sound decisions.

82. See supra note 56. 